\title{
Empirical Assessment of the Quality of Nationalities
}

\section{The Quality of Nationality Index (QNI)}

\author{
Dimitry Kochenov
}

Chair in Eu Constitutional Law, Faculty of Law, University of Groningen d.kochenov@rug.nl Justin Lindeboom

Doctoral researcher and lecturer, Faculty of Law, University of Groningen j.lindeboom@rug.nl

\begin{abstract}
Contemporary thinking about nationality is surrounded by three persistent mythologies. First, all nationalities are equal. Second, there is a direct correlation between the power and size of the economy of a country and the quality of its nationality. Third, there is a correlation between the geographical scope of the rights granted by a nationality and the territory of the conferring state. Looking beyond the subjective feelings one may have towards one's nationality, the widely diverging quality of nationalities can in fact be measured. In the Quality of Nationality Index, which this article introduces and discusses, an attempt has been made to develop and deploy a reliable and straightforward methodology to measure objectively the value of having a particular nationality, which would not be perception-based. Nationalities are not equal, at least not under the assumption that the level of expected welfare, education, healthcare, life chances, and global travel and settlement opportunities matter.
\end{abstract}

\section{Keywords}

nationality - citizenship - empirical studies - travel freedom - settlement freedom quality of nationality - QNI 


\section{Introduction}

Our task is to attempt to give an empirical twist to Brubaker's 'instrument and object of closure,', i.e. (national) citizenships. Contemporary thinking about nationality is surrounded by three persistent mythologies. First, that all nationalities are equal and that it is impossible to compare them because attachment to a country cannot be objectively measured. Second, that there is a direct correlation between the power and size of the economy of a country and the quality of its nationality. Third, that there is a correlation between the geographical scope of the rights granted by a nationality and the territory of the conferring state. These mythologies, however intuitive and unarticulated the patriotic excitement or the tenderness of feelings of attachment citizenship seemingly implies, are deeply entrenched in the thinking about nationality and citizenship, interfering with our capability to perceive the day-to-day reality in which each of these mythologies has proven to be false.

Looking beyond the subjective feelings one may have towards one's nationality, the widely diverging quality of nationalities can in fact be measured. By quantifying the value that any nationality grants its possessors, the abovementioned mythologies are easily dismissed, even though we fully realise, of course, that myths are not supposed to hold true: it is not the story they tell, it is what they $d o$, that matters, as Roland Barthes taught. ${ }^{2}$ Our task is then to show how problematic it is what they do in this particular case: exposing the myths we realize we are not necessarily undermining them thereby. In the Quality of Nationality Index (QNI), developed by Dimitry Kochenov with Chris Kälin and executed with the assistance from Justin Lindeboom, an attempt has been made to develop and deploy a reliable and straightforward methodology to measure objectively the value of having a particular nationality, which would not be perception-based. ${ }^{3}$ Ranking nationalities rather than countries per se is a deliberate choice, taking into account the increase in world migration flows as well as the lack of a correlation between the nationality held by a growing number of active individuals and the countries where their businesses are established and their lives are lived. This is the fundamental difference

1 R. Brubaker, Citizenship and Nationhood in France and Germany (Cambridge MA: Harvard University Press, 1992) 23.

2 R. Barthes, Mythologies, (trans. Annette Lavers) (New York NY: Farrar, Starus \& Giroux, 1972) 131 .

3 D. Kochenov (ed), Quality of Nationality Index, (2 ${ }^{\text {nd }}$ ed., Zürich: Ideos, 2017). For the on-line environment of the index, see www.nationalityindex.org. 
between the QNI and the absolute majority of other indexes and rankings, ${ }^{4}$ which take states - sovereign territorial entities - as their only reference point.

This contextualised QNI presentation is structured as follows. In Section 2, the transformation of citizenship leading up to the situation in which three key and widespread assumptions surrounding citizenship can no longer be maintained is illustrated. This is the story of citizenship becoming increasingly detached from the state, both in terms of the origin of citizenship rights as well as the scope of these rights. In Section 3, the three mythologies mentioned above are discussed, showing how each of them has lost any sensible meaning today. From this we describe in Section 4 the methodology of the QNI, proposing a manner in which the actual quality of nationalities can be measured and compared. The data of the Index can teach some useful lessons that demonstrate the relevance of measuring the quality of nationalities. Section 5 concludes.

2

\section{The Transformation of Citizenship}

The story of the absolute majority of the modern liberal democracies is a story of a constant nuancing of what citizenship entails and stands for, ${ }^{5}$ to the point when, as a result of a long evolution, it becomes clear that citizenship has gone through a fundamental overhaul over the last half century.

It is the normative core of citizenship as such, it seems, that is undergoing an intense and profound transformation. In the process all the foundational assumptions behind citizenship are being put to a test, including its ability to exclude without justification; ${ }^{6}$ its ability to oppress by imposing identities and to disregard the plight of those unable or unwilling to conform to the 'good citizen' ideal mandated by the authority; ${ }^{7}$ and its connection with a set of rights officially reserved for citizens only; ${ }^{8}$ as well as its ability, actually, not to extend equality before the law - citizenship's core consideration - to the groups out of

4 E.g. the Human Development Index, Global Peace Index, and the Rule of Law Index.

5 C. Joppke, Citizenship and Immigration (Cambridge: Polity Press, 2010).

6 I. Young, 'Polity and Group Difference', Ethics 99(2) (1989) 254-255; W. Forbath, 'Caste, Class, and Equal Citizenship', Michigan Law Review 98(1) (1999) 1.

7 R. van Oers et al (eds), A Redefinition of Belonging? (Leiden: Brill Nijhoff, 2010) 1; D. Kochenov, 'Mevrouw de Jong Gaat Eten: Eu Citizenship and the Culture of Prejudice', (2011) EUI Working Paper RSCAS 2011/06.

8 J. Carens, 'Citizenship and Civil Society: What Rights for Residents?', in R. Hansen and P. Weil (eds) Dual Nationality, Social Rights and Federal Citizenship in the U.S. and Europe (Santa Barbara: Randall Books, 2002) 100. 
favour with the authorities at any given moment: the women, the minorities, the communists, the poor. ${ }^{9}$

In particular in Europe the equality before the law, as well as the territoriality of the scope of any concrete citizenship's core rights is not as straightforward, seemingly, as the texts of the national constitutions would strongly imply, thus altering the concept's very core: the exclusive sovereign territoriality of this concept cannot any more be assumed, ${ }^{10}$ just like the idea that this legal status, alone, can provide a solid ground for the equal protection of all the bearers under the law of the authority that distributes the status." Even more, the paramount nature of citizenship as the ultimate status of protection, the emanation of the love of the country, the love, which by definition is not extended to those without the status, is in fact not what we see, as the discrimination on the basis of nationality, the core normative ideal of citizenship allowing the bearers to bathe in the rays of their motherland's love and look down at those who do not deserve this love by virtue of the place of birth, parentage, or both, is outlawed in the European Union. ${ }^{12}$ No, France does not love the Frenchmen more than Estonians. If it does, this could very well be a violation of EU law for the Commission and the European Court of Justice to look into. While the foundations of the core meaning of the legal bond that citizenship is have unquestionably evolved in the direction of relative loosening and the reduction in the perceived exclusivity, it is only a matter of time for the emotional bonds to follow suit, it seems. ${ }^{13}$ How many more Brexits are to

I. Tyler, 'Designed to Fail: A Biopolitics of British Citizenship', Citizenship Studies 14(1) (2010) ; K. Rundle, 'The Impossibility of an Exterminatory Legality: Law and the Holocaust', University of Toronto Law Journal 59(1) (2009) 69-76; A. Lester, 'East African Asians Versus the United Kingdom: The Inside Story' (lecture delivered on 23 October 2003).

10 T. Pullano, La citoyenneté européenne. Un espace quasi étatique (Paris: Presses de Sciences Po, 2014); D. Kochenov, 'Member State Nationalities and the Internal Market: Illusions and Reality', in: N. Níc Shuibhne and L.W. Gormley (eds) From Single Market to Economic Union (Oxford: Oxford University Press, 2012).

11 D. Kochenov, 'On Tiles and Pillars: eu Citizenship as a Federal Denominator', in: D. Kochenov (ed) EU Citizenship and Federalism: The Role of Rights (Cambridge: Cambridge University Press, 2017) 1.

12 Art 18 TfEu. G. Davies, “Any Place I Hang My Hat?” Or: Residence is the New Nationality', European Law Journal 11(1) (2005) 43.

13 Already now scholars discover strong variations between the levels of popular acceptance of the core consideration gong against the heart of what citizenship is about: non-discrimination on the basis of nationality: J. Gerhards, 'Free to Move? The Acceptance of Free Movement of Labour and Non Discrimination among Citizens of Europe', European Societies 10(1) (2008) 121. 
follow the discovery that the emotional bond of love between the citizen and the state is possibly not reciprocal; or, even worse, that the cold-hearted state is unfaithful with despicable countless others? ${ }^{14}$

Unlike what one could expect, the on-going transformation of citizenship has not resulted in the disruption of the global reality of inequalities. In fact, at a meta-level citizenship has turned into an astonishingly effective tool of the preservation of global inequalities. The gap between the poor and the rich societies is not going away and the 'paper citizens' ${ }^{15}$ of the global South have radically different rights and life chances compared with the citizens of the most affluent jurisdictions in the world. ${ }^{16}$ In a world where capital moves relatively freely, while the holders of the majority of the third world nationalities are locked within the boundaries of their states make the preservation of inequality function of citizenship crystal-clear.

This brings us to the most fundamental normative evolution that has been unfolding in the world of citizenship over the last decades in direct consequences of the developments briefly described above: citizen is being replaced with a person in the global constitutional parlance and theorizing. ${ }^{17}$ This is no small feat as a change in one word stands for a radical rethinking of the basics of modern constitutional systems marked by an intense penetration of the legal realities with the social facts overturning established constitutional underpinnings on a number counts. This fundamental transformation is in no sense illogical and draws entirely on the unsustainability, in the context of the human rights-aware democratic constitutionalism, of the traditional core normative assumptions informing citizenship, which are, unsurprisingly, being rethought. Considered together, the observations above thus have most far-reaching effects on the citizenship's role in the context of legitimizing the governing authority, its key tasks and its key normative predestination. Its role in the narrative of self-governance and democracy is thus not the same as before.

14 For the practical effect of Brexit on the massive loss of quality of UK citizenship that will affect all British nationals, see Section 4.5. below.

15 K. Sadiq, Paper Citizens: How Illegal Immigrants Acquire Citizenship in Developing Countries (Oxford: Oxford University Press, 2010).

16 A. Shachar, 'Children of a Lesser State: Sustaining Global Inequality through Citizenship Laws', Nomos 44 (2003) 345.

17 L. Bosniak, 'Persons and Citizens in Constitutional Thought', International Journal of Constitutional Law 8 (2010) 9. For analyses of the European perspective see D. Kochenov, 'Citizenship of Personal Circumstances in Europe', EUI Working Paper Law No. 2017/o7. 


\section{The Three Mythologies of Citizenship}

The profound transformation of citizenship notwithstanding, however, the abovementioned core normative assumptions of citizenship continue to uphold three persistent mythologies surround our contemporary concept of citizenship: that all nationalities are equal; that there is a direct correlation between the (economic) power or political importance of a country and the value of its nationality; and that there is a correlation between the geographical scope of rights associated with a nationality and the territory of the conferring state.

Looking beyond the formalities of black-letter international law, it is absolutely clear that nationalities diverge strongly in their practical value. It is not a secret that our nationalities have a direct impact on our lifestyles, freedom to think independently, do business, and live longer, healthier, and more rewarding lives. The extremes are well-known - a child in Nigeria is 38 times more likely not to survive the first five years of life than a child in the United Kingdom; or Afghans and Iraqis are infinitely less likely to experience London, Los Angeles or Tokyo than, say, Austrians and Australians. It is better to have a nationality of a country with long life expectancy, a good schooling system and a high level of prosperity - like Norway - than of a country which offers lower levels of security, schooling and health to its nationals - like Moldova. It is better to have a nationality and as a consequence, enjoy the rights to work and reside, in a country with a large economy - like Germany - than in a tiny country, however prosperous, like Monaco. It is better to have a nationality of a peaceful and stable country, like Switzerland, than of a country with security risks, like Pakistan.

The argument that the value of nationalities is unquantifiable, because the patriotic feelings experienced by nationals towards their country - 'a social fact of attachment, a genuine connection of existence, interests and sentiments' in the notable words of the International Court of Justice's Nottebohm judgment ${ }^{18}$ is difficult to defend. In today's globalised world, identities overlap ${ }^{19}$ and the most active part of the population has lived abroad, sometimes for a considerable amount of time and is likely to hold more than one passport. ${ }^{20}$ Additionally,

\footnotetext{
18 Nottebohm (Liechtenstein v Guatemala) (1955) ICJ Reports 4.

19 W. Kymlicka, Multicultural Citizenship: A Liberal Theory of Minority Rights (Wotton-underEdge: Clarendon Press, 1995); P.J. Spiro, At Home in Two Countries: The Past and Future of Dual Citizenship (New York: NYU Press, 2016).

20 On the analysis of the pros and cons of dual nationality see D.A. Martin, 'New Rules on Dual Nationality for a Democratizing Globe: Between Rejection and Embrace', Georgetown
} 
regardless of the subjective feelings people may or may not have towards their nationality, the living environment in one's home country - welfare, education level, life expectancy, etc. - as well as one's global opportunities are quantifiable, and quality differences between nationalities are measurable.

It would be a grave mistake, however, to identify the quality of nationality with the quality of the conferring state. The quality of nationalities is not always reflected in basic characteristics like economic power or the level of development of the countries with which such nationalities are associated. What your nationality allows you to do outside your home country matters at least as much as living standards within it. Thus, economically strong countries can have relatively unattractive nationalities insofar as they do not allow their nationals to settle freely in other countries (such as China and the Chinese nationality as well as Canada and the Canadian nationality). Conversely, small economies can offer nationalities of great value (such as Slovenia and the Slovenian nationality) precisely because they are gold-plated with the perks of EU citizenship, securing access to thirty other nations and home-treatment there, what Canadian and the Chinese nationality does not do. Likewise, in terms of tourist and business travel, a Chinese passport grants visa-free or visa on arrival access to 53 countries only and is easily surpassed by the same tiny Slovenia, with visa-free or visa on arrival access to 164 countries. Perhaps the most obvious example is given by those people who possess the nationality of Iran or Yemen and early this year were suddenly confronted with the impossibility to enter the territory of the United States regardless of any personal circumstances or any other nationality they hold: it is time to admit that the quality of nationalities varies to the extent that a low quality nationality can be a liability, rather than an empowering bundle of rights.

A related consideration to mention is as important: the hitherto unquestioned correlation between citizenship rights and sovereign territory is changing in many places. The Eu may remain a blueprint, but is hardly an anomaly: more and more nationalities around the world secure access to key citizenship rights - including residence, work and, also, not infrequently political rights outside the confines of the sovereign territory whose authority is behind the grant of the legal status of citizenship in the first place. Importantly, this does not only concern the (quasi-)citizenship of the (formerly) subordinated

Immigration Law Journal 14(1) (1999) 1; P.J. Spiro, 'Dual Nationality and the Meaning of Citizenship', Emory Law Journal 46(4) (1997) 1411; L. Bosniak, 'Multiple Nationality and the Postnational Transformation of Citizenship', Virginia Journal of International Law 42(4) (2002) 979. See also P.J. Spiro, 'Dual Citizenship as Human Right', International Journal of Constitutional Law 8 (2010) 111. 
colonies which, through some version of a 'compact of free association'21 with what used to be the 'mother country' would extend the rights in the colonial centre to the former colonial subjects: think of the Micronesians rom the Federated States in the Us ${ }^{22}$ or - if not stretching it - Belarussians in Russia. ${ }^{23}$ The logic of opening up the sovereign territory and thus, potentially, the access to the citizenship status as such for each-other's citizens, first proposed by A.V. Dicey in the end of the $19^{\text {th }}$ century, ${ }^{24}$ while only destined to find cold reception then, came to work well around the world today. In addition to the $\mathrm{EU}$, from the Gulf Cooperation Council in the Middle East, ${ }^{25}$ to MERCOSUR in Latin America, ${ }^{26}$ ECOWAS in West Africa (at least on paper), ${ }^{27}$ and the Nordic countries, ${ }^{28}$ the dislocation of the citizenship-sovereign territory correlation has turned into a fundamentally important trend in the contemporary citizenship evolution, what one might brand as the rise of inter-citizenships penetrating two or more jurisdictions via the same legal status enhanced through the binding requirement of mutual recognition. The extent of proliferation of the world's intercitizenships is illustrated by the map in figure 1 .

21 C.I. Keitner and W.M. Reisman, 'Free Association: The United States Experience', Texas International Law Journal 39(1) (2003) 1.

22 T. Lam Dang, 'Relation associative: les États Fédérés de Micronésie: les spécificités de l'association', in: J. Faberon et al. (eds) Destins des collectivités politiques d'Océanie, Vol 1 (Marseille: Presses Universitaires d'Aix-Marseille, 2011).

23 N.A. Voronina, 'Sojuznoje gosudarstvo Rossija - Belarus: opyt pravovogo regulirovanija', NB: Mezhdunarodnoje parvo 3 (2013) 52.

24 L. Dyer, 'Anglo-Saxon Citizenship: A Proposition by Professor Dicey Looking to This End', The Barrister 3 (1897) 107. The new status was to be inaugurated on 1 January 11901 , but the proposal did not generate enough following for this plan to become a reality.

25 Z. Babar, 'Free Mobility within the Gulf Cooperation Council' (2011) Occasional Paper No 8 (Center for International and Regional Studies, Georgetown University School of Foreign Service in Qatar).

26 D. Acosta Arcarazo, 'Turning the Immigration Policy Paradox Upside Down? Populist Liberalism and Discursive Gaps in South America' International Migration Review 49(3) (2015) 659. See also D. Acosta Arcarazo and A. Geddes, 'Transnational Diffusion or Different Models? Regional Approaches to Migration Governance in the European Union and MERCOSUR', European Journal of Migration \& Law 16 (2014) 13.

27 A. Adepoju, 'Fostering Free Movement of Persons in West Africa: Achievements, Constraints, and Prospects for Intraregional Migration', International Migration 40 (2002) 3; A. Adepoju, 'Migration Management in West Africa within the Context of Ecowas Protocol on Free Movement of Persons and the Common Approach on Migration', in: OECD (ed) Regional Challenges of West African Migration (Paris: OECD Publishing, 2009) 17.

28 M. Kuisma, 'Nordic Models of Citizenship: Lessons from Social History for Theorising Policy Change in the "Age of Globalisation"', New Political Economy 12 (2007) 87. 


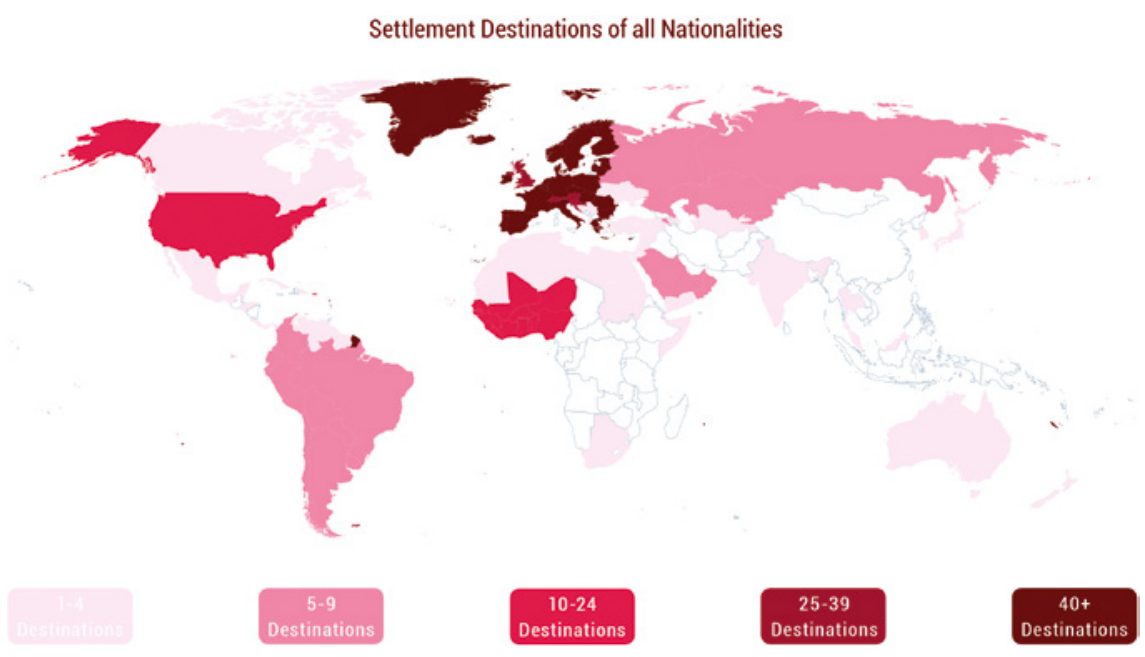

FIGURE 1 Intercitizenships of the world, 2017 (QNI 2017)

4

The Quality of Nationality Index

Once it is acknowledged that the three myths surrounding nationality have no connection to reality, building a methodology for measuring the actual value of nationalities is only logical. The QNI is the first index to provide a comprehensive ranking of the quality of nationalities worldwide. A wide variety and depth of sources have been used to gauge the opportunities and limitations that our nationalities impose on us. For that purpose, the QNI measures both the internal value of nationality, which refers to the quality of life within a nationality's country of origin, and the external value of nationality, which identifies the diversity and quality of opportunities that nationalities allow us to pursue outside our countries of origin. Since virtually all nationalities allow their holders to travel abroad and, moreover, a significant number of nationalities allow their holders to work and live in different countries abroad as well, the value of having a particular nationality can no longer be based on the qualities of the issuing country itself - indeed this is the core thought behind the QNI. All the sources used are objectively verifiable and build on the data collected by the leading international institutions with impeccable reputation.

Building on a presumption that for a reliable comparison both internal and external factors are important, internally, we look at how successful the country is in terms of human development, economic prosperity, and stability and peace. In this regard the QNI measures the quality of nationalities by reference 
to the countries to which they are associated, creating a compound value derived from authoritative sources. What makes the QNI particularly innovative, however, is taking into account the 'external value' of nationalities as well. External factors are no less important than internal ones: some nationalities give their passport holders the ability to travel around nearly all the world unobstructed by visa requirements, no questions asked - think of the German nationality, for instance - while others make tourist and business travel dependent on acquiring endless visas, or at times, de facto impossible - think of an Armenian wishing to visit Baku. Moreover, some nationalities not only allow their holders to travel abroad, but give a right to full 'home treatment' in other countries as well. The QNI takes into account both the freedom to travel as well as the freedom to settle in other countries in evaluating the external value of each nationality.

\subsection{Internal Value: Economic Strength, Human Development, Peace and Stability}

The first of three sub-elements composing the internal value of nationalities is the level of human development in the corresponding country. The basic level of development associated with a nationality provides a rough prophecy for the average person's life prospects. Thus, the importance of the level of human development for the quality of a nationality requires little elaboration; the overwhelming majority of people spend most of their lives in their home country, and are profoundly affected by the basic level of its development. Also in a globalized world, human development in the country of origin will always substantially affect our life prospects, including the ability to become a global citizen later in life.

The QNI derives the degree of human development from the United Nations Development Programme Human Development Index (HDI), which is today's most authoritative ranking of basic human development. ${ }^{29}$ The HDI is an annual index based on the idea that the development of a country is not reflected in its economic strength or growth per se, but in its people and their capabilities. Designed by the Pakistani economist Mahbub ul Haq together with a team of economists including Nobel Laureate Amartya Sen, the HDI evaluates non-economic development in the simplest possible manner, ${ }^{30}$ measuring

29 For the most recent edition of the HDI, see Human Development Report 2016. Human Development for Everyone (United Nations Development Programme 2016) 198-201.

30 As Sudhir Anand and Amartya Sen note, the HDI 'has been concerned only with the enhancement of very basic capabilities of people', S. Anand, A.K. Sen, Human Development Index: Methodology and Measurement, HDR Occasional Papers (1994) 12. 
three dimensions of human development: health, education and standard of living. ${ }^{31}$ HDI scores do not reflect inequalities, poverty, human security, empowerment, or other factors directly, ${ }^{32}$ although the factors obviously exert influence on the levels of health, education and standard of living indirectly. ${ }^{33}$ HDI scores are directly mirrored in the Human Development component of the QNI: the higher the country's score on the HDI, the higher the Human Development score of the corresponding nationality.

While the HDI takes into account general welfare through GDP per capita, the quality of a nationality is equally influenced by the scale of opportunities. Being a national of the us, for example, enables someone to pursue endless opportunities without crossing national borders. In this regard us nationality is more valuable in comparison to the nationality of, for example, Brunei, even though the latter has slightly higher GDP per capita. Accordingly, the second internal element of the QNI measures the economic strength of the country that grants the status in terms of the country's GDP. ${ }^{34}$ Economic strength is

31 Human Development Report 2016, 222-258. For critical analysis of the HDI and its methodology, see e.g. N.C. Lind, 'Some Thoughts on the Human Development Index', Social Indicators Research 27 (1992) 89; T.N. Srinivasan, 'Human Development: A New Paradigm or Reinvention of the Wheel?', American Economic Review 84 (1994) 238; A. Sagar and A. Najam, 'The Human Development Index: A Critical Review', Ecological Economics 25 (1998) 249; K. Raworth and D. Stewart, 'Critiques of the Human Development Index: A Review', in: S. Fukuda-Parr and A.K. Shiva (eds Readings in Human Development (Oxford: Oxford University Press, 2003); R. Veenhoven, 'Apparent Quality-of-Life in Nations: How Long and Happy People Live', Social Indicators Research 71 (2005) 61; M. Kovacevic, 'Review of HDI Critiques and Potential Improvements' (2010) Human Development Research Paper 2010/33.

32 The UNDP does however publish complementary indices: the Inequality-adjusted $\mathrm{Hu}-$ man Development Index, the Gender Development Index, the Gender Inequality Index, and the Multidimensional Poverty Index. See for a data overview Human Development Report 2016, 206-219.

33 J.L. Murray, 'Development Data Constraints and the Human Development Index', in: D.G. Westerndorff and D. Ghai (eds) Monitoring Social Progress in the 19gos (Geneva: UNRISD, 1993) 40; M. Kovacevic, 'Measurement of Inequality in Human Development - A Review' (2010) Human Development Research Paper 2010/35.

34 GDP can be defined as the sum of gross value added by all resident producers in the economy plus any product taxes and minus any subsidies not included in the value of the products (see e.g. World Development Indicators 2008 (World Bank 2008) 205; and oecD, 'Gross Domestic Product'. Retrieved 14 September 2017 data.oecd.org/gdp/gross -domestic-product-gdp.htm). GDP at PPP data is taken from the World Bank database. Retrieved 14 September 2017 data.worldbank.org/data-catalog/GDP-PPP-based-table. On measuring GDP, see further T. Callen, 'Gross Domestic Product: An Economy's All'. 
all about scale: stronger economies offer more opportunities in private and professional life, creating more value for their nationals. Therefore, the larger the country is economically, the stronger its economic strength is and hence, the higher the score is of the corresponding nationality, reflecting the greater number of life chances it offers. ${ }^{35}$

GDP is measured at Purchasing Power Parity (PPP) - which converts countries' GDP into international dollars ${ }^{36}$ - and excluding Natural Resources Rents (NRR). ${ }^{37}$ As an international dollar is defined by having the same purchasing power as a US dollar has in the US, applying PPP makes the size of economies more comparable because the GDP figures reflect the actual size of the economy from a consumer perspective. NRR are excluded from the measurement of economic strength to avoid substantial distortion of the value of some nationalities. While economic strength is principally intended to reflect all economic opportunities granted to holders of a nationality, NRR is not suitable to reflect the genuine scale of a country that works to the benefit of its nationals. Some African and Middle Eastern countries, for example, have relatively large

International Monetary Fund, Finance \& Development 2012. Retrieved 14 September 2017 www.imf.org/external/pubs/ft/fandd/basics/gdp.htm.

35 This is notwithstanding the fact the GDP clearly has limits as a measurement of welfare and standard of living. See e.g., R.A. Easterlin, 'Does Economic Growth Improve the Human Lot? Some Empirical Evidence in Nations and Households', in: P.A. David and M.W. Redner (eds) Economic Growth: Essays in Honor of Moses Abramovitz (Gent: Academic Press, 1974) 98; R. Costanza, M. Hart, S. Posner and J. Talberth, 'Beyond GDP: The Need for New Measures of Progress', Boston University Pardee Papers 4 (2009); Michael Green, 2015. 'Why We Shouldn't Judge a Country by its GDP'. Ideas.ted.com, April 22. Retrieved 14 September 2017 www.ideas.ted.com/why-we-shouldnt-judge-a-country -by-its-gdp/;The Trouble with GDP’. Economist, 30 April 2016. Retrieved 14 September 2017 www.economist.com/news/briefing/21697845-gross-domestic-product-gdp-increasingly -poor-measure-prosperity-it-not-even. For the purpose of the QNI, however, GDP is purely used as a derivative indicator of scale, rather than welfare per se.

36 On calculating PPP, see Global Purchasing Power Parities and Real Expenditures 2005 International Comparison Program (World Bank 2008); A. Deaton and A. Heston, 'Understanding PPPs and PPP-based national accounts', American Economic Journal: Macroeconomics 2(4) (2010) 1 .

$37 \quad$ NRR are the rents from the exploitation of natural resources, oil, natural gas, coal (hard and soft), minerals, and forests. NRR data is taken from the World Bank database. Retrieved 14 September 2017 data.worldbank.org/indicator/NY.GDP.TOTL.RT.ZS. See further The Changing Wealth of Nations: Measuring Sustainable Development in the New Millennium (World Bank 2011); R. Cronin and A. Pandya, Exploiting Natural Resources: Growth, Instability and Conflict in the Middle East and Asia (Washington: The Henry L. Stimson Center, 2009). 
economies that are substantially dependent on NRR, distorting the values of their nationalities, since their economic strength is not reflected in the scale of economic and social opportunities that their nationals enjoy.38

Lastly, the QNI incorporates the level of peacefulness and stability of the corresponding countries into the internal value of nationality. A peaceful society likely fosters human development, welfare and happiness more than anything else. ${ }^{39}$ Conversely, war and violence can dramatically affect the fate of having a particular nationality, in particular for nationalities that grant their holders few to no global opportunities. For measuring Peace and Stability, the QNI uses figures from the annual GPI published by the Institute for Economics and Peace. ${ }^{40}$ The GPI is an annual ranking that measures the peacefulness, stability and harmony of countries by looking at 23 indicators of peace, divided into three domains: ongoing domestic and international conflict, the level of harmony within a nation and the degree of militarization. ${ }^{41}$

\subsection{External Value: Travel and Settlement}

The QNI measures the extent to which a nationality gives its holders the opportunity to travel freely without extensive administrative hassles and timeconsuming preparation. Visa restrictions play an important role in controlling the possibilities for (foreign) nationals to travel freely across borders. Almost all countries now require visas from certain non-nationals who wish to enter (or leave ${ }^{42}$ ) their territory. In most countries, a tourist and business access visa allows you to stay in the country between one and three months. Visa applications cannot only be time-consuming: for holders of some nationalities they are actually unpredictable and at worst unlikely to be successful. In the cases of some nationalities, access to certain countries for tourist or business purposes is de facto impossible. Holders of Armenian passports intending to see Azerbaijan, or Israelis intending to do business in some Arab countries are the cases in point. Even in a globalized world where virtually any place on Earth can be reached in the blink of an eye, visa restrictions pose serious constraints,

38 See further, J.D. Sachs and A.M. Warner, 'The Big Rush, Natural Resource Booms And Growth', Journal of Development Economics 59 (1999) 43; J.D. Sachs and A.M. Warner, 'The Curse of Natural Resources', European Economic Review 45 (2001) 827; J.P. Stijns, 'Natural Resource Abundance and Economic Growth Revisited' Resources Policy 30 (2005) 107. See e.g., The Economic Value of Peace 2016 (Institute for Economics \& Peace 2016).

40 Global Peace Index 2016. Ten Years of Measuring Peace (Institute for Economics \& Peace 2016).

41 Ibid 95-112.

42 D. Kochenov, 'The Right to Leave Any Country Including Your Own in International Law', Connecticut Journal of International Law 28 (2012) 43. 
and unfortunately for some nationalities this constraint is much more serious than for others.

More importantly, some nationalities come with a right to be welcomed by other countries and societies - a right to 'home' treatment. In this sense, possessing one nationality can amount to enjoying plentiful rights, including work and settlement, in a number of states, not just one. Settlement in a particular country is considered possible if 1 . an adult holder of a nationality is allowed to work without having to obtain a visa or with visa on arrival, and 2. permission to work in that country is either not required or virtually automatic. The Icelandic nationality for example, although conferred by a tiny country, gives its bearers full access to all the EU Member States including Greenland, the Faeroe Islands, seven French overseas regions and collectivities and Gibraltar, all the countries of the European Economic Area and the Nordic Union. Icelanders are equally at home in 41 countries and territories, enjoying all the rights which the bearers of the local nationalities there enjoy. Compare this with Canadian nationality, which - although the country is as prosperous - not associated with such extra-territorial rights and the difference becomes clear.

In determining the freedom to settle in another country, the QNI does not consider entitlement to public pension systems; entitlement to health care; entitlement to social security benefits; allowance to family members to join the person in question; and specific skill qualifications that are required to perform certain professions, particularly of a qualitative nature, e.g., bar qualifications to practice as lawyer, medical qualifications to practice as a doctor, or construction worker qualifications. This is simply because it is not our intention to define settlement freedom as giving the holder of a nationality an unconditional carte blanche in a different country, which understandably does not exist anywhere in the world anyway.

\subsection{Diversity and Weighed Value of Travel and Settlement}

Travel and settlement freedom can each be viewed from two perspectives. First, there is the sheer number of destinations to which one can travel to visafree or by visa-on-arrival, and the number of destinations in which one can settle freely. Diversity of opportunity matters greatly, which is why the variety of choices one has for travel or settlement is valued explicitly. However, this purely quantitative approach has clear limitations in terms of practical value. Certainly not all countries are equally valuable and equally worth traveling to. For most people, being able to travel freely to the EU or the United States will be more valuable than having no visa obligation for some of the developing countries. To give a clear example, in 2016 a Russian passport gave visa-free or visa-on-arrival tourist and business access to 106 countries. However, none of 
the destinations to which nationals of Russia may travel without a visa are firstworld countries: prior visa application is still necessary for, amongst others, the US, EU countries, Australia, Japan and Canada. By comparison, nationals of Moldova or Serbia had a similar number of free travel destinations (102 and 114 respectively), including both however visa-free access to the Schengen area, which is an asset that Russian nationality lacks.

In other words, it also matters what kind of countries exactly one can travel to or settle in with a particular nationality. ${ }^{43}$ In this sense, being able to travel to Switzerland visa-free is of higher added value than being able to visit Georgia visa-free. The same applies to settlement: having the unconditional right to work and live in Denmark which is associated with a Liechtenstein nationality, for instance, places Liechtensteiners above all European non-EU/EEA or Swiss nationals whose nationalities have no such association, such as a Ukrainian nationality. For this reason, the QNI separately takes into account the weight of travel freedom as well as the weight of settlement freedom, both of which are based on an aggregation of the human development and economic strength of all possible destinations to which a nationality allows you to travel visa-free or by visa-on-arrival (in the context of Weight of Travel Freedom) or grants you full-access rights, including rights to work and to settle (in the context of Weight of Settlement Freedom). ${ }^{44}$ The QNI consequently measures both the Diversity as well as the Weight of Travel and Settlement Freedom, whereby Diversity and Weight are valued equally.

The exact destinations that nationalities allow their holders to visit visafree or by visa-on-arrival are not publicly available. Therefore, travel freedom data are provided specifically for the QNI by the International Air Transport Association (IATA), which manages the largest and most accurate database on worldwide visa regimes. Since there exists no equivalent database containing the global settlement opportunities attached to nationalities, settlement freedom data is gathered through extensive literature research on the legal requirements on settlement throughout the world, complemented with

43 This aspect is not taken into account by the Henley \& Partners Visa Restrictions Index, which, although providing useful information on the number of visa-free travel destinations for each nationality, has limited value in terms of genuinely measuring the quality of travel freedom.

44 The 'destination value' of each country is given by the sum of the normalized Human Development score (on a $0-15$ scale) and the normalized Economic Strength score (also on a $0-15$ scale). Thus, each destination contributes to the Weight of Travel Freedom value of a nationality a value between $o$ and 30 . The Weight of Travel Freedom value of a nationality is then the sum of all those 'destination values'. This value it subsequently normalized itself to a $0-15$ scale to make it commensurable with the other sub-elements. 
consultations with experts in all regions of the world. This ensures that only real and genuine settlement freedom is taken into account, and paper tigers or sham legal freedoms are discarded. ${ }^{45}$

\subsection{Measurement and Rankings}

From the aggregation of the internal and external elements that we have identified above, the quality of nationalities is composed of seven sub-elements: the level of human development in the nationality-conferring country; the economic strength of the nationality-conferring country; the degree of peace and stability in the nationality-conferring country; the diversity of settlement freedom; the weighed value of settlement freedom; the diversity of travel freedom; and the weighed value of travel freedom. Thus, the QNI General Ranking ranks the nationalities' value most broadly interpreted, including internal opportunities, welfare and life prospects, as well as the freedom to travel and settle throughout the world. In the most comprehensive manner possible, the QNI General Ranking can be said to gauge quality of life in a globalized world.

Nationalities are ranked on a scale from o percent to 100 percent. The following weights are attributed to the separate sub-elements:

1. Human development: 15 percent

2. Economic strength: 15 percent

3. Peace and stability: 10 percent

4. Diversity of settlement freedom: 15 percent

5. Weight of settlement freedom: 15 percent

6. Diversity of travel freedom: 15 percent

7. Weight of travel freedom: 15 percent

As regards the internal value of nationalities, Peace and Stability is given lower weight than Human Development and Economic Strength for two reasons. In the first place it is highly volatile. While the overwhelming majority of people will keep their nationalities for life, the peacefulness of many regions is far less stable. Secondly, elements of peace and stability are also reflected in the measurement of human development and economic strength. While neither GDP measurements nor the Human Development Index takes peacefulness into account directly, it is beyond doubt that a more peaceful and stable society generally results in a more prosperous economy offering more life chances, and is more likely to have a higher level of wealth, education and health and welfare in general.

45 See further Kochenov, The Quality of Nationality Index (n 3) Part I: Methodology'. 
The sub-elements of the QNI are the normalized scores of the nationalities. Data from the various sources is normalized by transforming the results to a scale that corresponds with the weight that is given to particular sub-element (10 percent for Peace and Stability and 15 percent for all other sub-elements). Each nationality is thus awarded a score based on its relative performance visà-vis the other nationalities.

For example, in 2016 the world's most peaceful country according to the GPI was Iceland with a score of 1.19. The Icelandic nationality's Peace and Stability score is accordingly a full score of 10 percent. Germany received a GPI score of 1.486. As the GPI applies a linear scale on which the lower the score, the more peaceful the country, German nationality is given a QNI Peace and Stability score of 1.19 (Icelandic's GPI) divided by 1.486 (Germany's GPI) and multiplied by 10 (the full Peace and Stability score) $\approx 8$.oo.

For all other sub-elements, nationalities are given a ranking on a scale from $o$ to 15 . The highest scoring nationality will always receive full 15 percent, while other nationalities are ranked proportionately. For example, in 2016 China was the strongest economy with 16.82 percent of world GDP (PPP) excluding NRR. Chinese nationality is thus given a full 15 percent on Economic Strength. By contrast, the United States contributed 15.93 percent of PPP world GDP excluding NRR. US nationality consequently scores on Economic Strength as 15.93 divided by 16.82 and multiplied by $15 \approx 14.20$ percent. Looking at another example with regard to Diversity of Travel Freedom, in 2016 nationals of Germany could travel visa-free or by visa-on-arrival to 176 countries, surpassed in quantity by no other nationality and thus earning a full 15 percent score. Qatari nationals, by contrast, had such travel access to 78 countries. The normalized Diversity of Travel Freedom score of the Qatari nationality is accordingly equal to 78 divided by 176 , and multiplied by $15 \approx 6.65$ percent.

The quality of nationality is calculated by adding up the scores of the seven sub-elements. For example, United States nationality received the following scores: 14.54 percent on Human Development, ${ }^{46} 14.20$ percent on Economic Strength, ${ }^{47} 5.53$ percent on Peace and Stability, ${ }^{48} 2.73$ percent on Diversity of

46 The Us's HDI score is 0.915 . Norway being the highest-scoring country in the HDI with 0.944, the normalized Human Development score of the Us is given by $0.915 / 0.944 * 15$.

47 The Us's \%worldG DP (excluding NRR) is 15.9 percent. China's \%worldG DP being the highest of all countries with 16.8 percent, the normalized Economic Strength of the Us is given by $0.159 / 0.168 * 15$.

48 The US's GPI score is 2.154. Iceland is the most peaceful country with a GPI of 1.192 (unlike other sources of the elements of the QNI, in the GPI lower = better). The normalized Peace and Stability of the US is given by $1.192 / 2.154$ * 10 . 
Settlement Freedom, ${ }^{49}$ 2.35 percent on Weight of Settlement Freedom, ${ }^{50} 14.83$ percent on Diversity of Travel Freedom, ${ }^{51}$ and 14.66 percent on Weight of Travel Freedom. ${ }^{22}$ The overall score of United States nationality is thus 14.54 percent + 14.20 percent +5.53 percent +2.73 percent +2.35 percent +14.83 percent + 14.66 percent $=68.84$ percent, or a 29 th place on the QNI General Ranking.

In the QNI 2016, the application of the methodology described above results in the following top 10 :

TABLE $1 \quad$ QNI General ranking 2016, top 10

\begin{tabular}{lll}
\hline $\mathbf{1}$ & Germany & 82,7 \\
$\mathbf{2}$ & France & 82,4 \\
$\mathbf{2}$ & Denmark & 82,4 \\
$\mathbf{3}$ & Iceland & 81,3 \\
$\mathbf{4}$ & Sweden & 81,2 \\
$\mathbf{5}$ & Norway & 81,0 \\
$\mathbf{6}$ & Finland & 80,7 \\
$\mathbf{7}$ & Austria & 79,9 \\
$\mathbf{7}$ & Italy & 79,9 \\
$\mathbf{8}$ & Netherlands & 79,7 \\
$\mathbf{9}$ & Switzerland & 79,6 \\
$\mathbf{1 0}$ & Spain & 79,5 \\
& & \\
\hline
\end{tabular}

49 Us nationals have full access to 8 settlement destinations. With French nationals having 44 full access settlement destinations (the highest score), the normalized Diversity of Settlement Freedom score of the us is given by $8 / 44 * 15$.

50 The combined weighed value of the 8 settlement destinations accessible by us nationals each given by the sum of the sum of normalized HDI and normalized \%world GDP of each settlement destinations - is 90.03. The weighed value of French nationality's 44 settlement destinations is 574.65. The normalized Weight of Settlement Freedom score of the Us is given by $90.03 / 574.65 * 15$. It is also clearly visible that here that the kind of settlement destinations matter. The weighed value of the settlement destinations of Us nationals is relatively low with an average 11.25 per settlement destination on a $0-30$ scale. By comparison, the weighed value of settlement destinations of French nationals is significantly higher with 13.06 on a $0-30$ scale.

$5^{1} \quad$ US nationals have visa-free or visa-on-arrival access to 174 destinations, while the German nationality received the highest score with access to 176 such destinations. The normalized Diversity of Travel Freedom score of the US is given by $174 / 176 * 15$.

$5^{2}$ The combined weighed value of the 174 visa-free or visa-on-arrival destinations for us nationals is 2034.17, while that of the 176 such destinations for German nationals is 2081.18. The normalized Weight of Travel Freedom score of the us nationality is given by $2034.17 / 2081.18 * 15$. 
TABLE 2 QNI General ranking 2016, bottom 10

\begin{tabular}{lll}
\hline 148 & Ethiopia & 18,2 \\
149 & Burundi & 18,0 \\
150 & Pakistan & 17,4 \\
$15^{1}$ & Syrian Arab Republic & 17,2 \\
$15^{2}$ & Yemen & 17,0 \\
$15^{2}$ & Sudan & 17,0 \\
153 & Congo (Democratic Republic of the) & 16,9 \\
154 & Eritrea & 16,6 \\
155 & Central African Republic & 16,3 \\
156 & Afghanistan & 14,6 \\
\hline
\end{tabular}

The immense quality difference between the most valuable and the least valuable nationalities which are actually a regrettable liability for the holders needs no further explanation, looking at the scores of the 10 lowest-scoring nationalities:

The QNI also quantifies the external value of nationalities separately, in order to identify which nationalities score highest with a view to global travel and settlement opportunities. Accordingly, the External Value Ranking is composed of all four external sub-elements of the QNI, with the following weights attributed to each of them:

1. Diversity of settlement freedom: 25 percent

2. Weight of settlement freedom: 25 percent

3. Diversity of travel freedom: 25 percent

4. Weight of travel freedom: 25 percent

The methodology for measuring the four sub-elements is equal to that for measuring the same elements in the context of the QNI General Ranking, with the exception of the $0-25$ normalized scale for each of the elements. In other words, the highest-scoring nationality in any of the given sub-elements receives the full 25 percent score, while others are ranked proportionately. This results in the following top 10 of highest-scoring nationalities:

Lastly, the QNI can also looks at travel freedom specifically, with Diversity and Weight of Travel Freedom each counting for $5^{\circ}$ percent. In this case EU nationalities do not have a similar monopoly in the top rankings as they possess in the General Ranking and the External Value Ranking. The nationalities of countries like Japan and Singapore - which were even occupying the 1st and 
TABLE 3 QNI External value ranking 2016, top 10

\begin{tabular}{lll}
\hline 1 & France & 99,5 \\
2 & Sweden & 97,1 \\
3 & Finland & 96,9 \\
4 & Denmark & 96,6 \\
5 & Norway & 96,4 \\
6 & Italy & 96,0 \\
7 & Germany & 95,2 \\
8 & Iceland & 95,1 \\
9 & Spain & 94,8 \\
10 & Belgium & 94,5 \\
\hline
\end{tabular}

TABLE 4 QNI Travel freedom ranking 2016, top 10

\begin{tabular}{llr}
\hline 1 & Germany & 100,0 \\
2 & Sweden & 99,5 \\
3 & Finland & 99,1 \\
4 & Spain & 99,0 \\
4 & Italy & 99,0 \\
4 & France & 99,0 \\
5 & United Kingdom & 98,9 \\
6 & Belgium & 98,5 \\
6 & Netherlands & 98,5 \\
7 & Denmark & 98,4 \\
7 & Japan & 98,4 \\
7 & Singapore & 98,4 \\
8 & United States & 98,3 \\
8 & Channel Islands & 98,3 \\
8 & Isle of Man & 98,3 \\
9 & Norway & 98,0 \\
10 & Luxembourg & 97,9 \\
10 & Austria & 97,9 \\
\hline
\end{tabular}

2nd positions in previous editions of the QNI Travel Freedom Ranking53 - are able to maintain themselves in the top ranks by ensuring visa-free and/or visaby-arrival travel access to many highly developed countries for their nationals.

53 See D. Kochenov (ed), The Quality of Nationalities Index, ( $1^{\text {st }}$ ed., Zürich: Ideos, 2016). 
Visa waiver agreements are often the result of good diplomatic relations and good reputation of countries and their nationals. As such, countries are able to secure or even improve the quality of their nationalities directly by maintaining good relations with other states and securing democracy and the Rule of Law within their borders.

\subsection{Some Useful Lessons}

The unsustainability of the three mythologies of citizenship described above is one of the primary lessons that the QNI aims to teach. The inequality of nationalities is undeniable, looking at the extreme ends of the quality spectrum. The added value of transnational citizenship rights, the presence and value of rights associated with a particular nationality beyond the conferring state's territory is aptly illustrated by the great quality difference between nationalities that grant such rights and those that do not. This is not just about the European Union, however. Nationalities of the Member States of EcowAS in Africa, MERCosur in South America, and the Gulf Cooperation Council in the Middle East are clearly distinguishing themselves positively from other nationalities in their respective regions as a result of free movement between Member States. ${ }^{54}$ While currently the EU is still provides the highest level of integration, offering the most elaborate range of transnational citizenship rights, other regional organizations exemplify the same trend.

One could go further by looking at the practical irrelevance of national citizenship rights that regional integration brings about. Looking at EU citizenship, so long as, by virtue of this status, EU citizenship grants Europeans with rights in 28 states instead of only one and any discrimination on the basis of nationality is prohibited, Article 18 of the Treaty on the Functioning of the European Union entails the abolition of the nationalities of the Member States, as Gareth Davies observed. ${ }^{55}$ However, EU citizenship's crucial role in contributing to the real value for individuals is not only illustrated by the fact that the objective value of nationalities of the Member States far exceeds that of any other state, but particularly by UK citizenship's vast loss of value that Brexit will inevitably cause. The hard figures of the QNI demonstrate that 'taking back control' has a high price - not just in purely economic terms - for all UK citizens: their quality of nationality will immediately lose 32 percent of its value. ${ }^{56}$

54 See Kochenov, The Quality of Nationality Index $\left(\mathrm{n}_{3}\right)$ for several regional rankings, illustrating the effect of regional integration on the quality of the nationalities of the countries concerned.

55 Davies, “'Any Place I Hang My Hat?" or: Residence is the New Nationality' (n 12) 43, 55 .

$5^{6}$ In 2016 U n nationals had settlement access to 38 countries. Diversity of settlement following Brexit entails 36 fewer settlement destinations (26 EU Member States (excluding 
An opposing but equally significant lesson is given by the positive implications of the visa waiver between the $\mathrm{EU}$ and the United Arab Emirates. On the 6th of May 2015, the EU gave UAE nationals visa-free access to the 26 travel destinations of the Schengen area, plus 8 non-Schengen countries in Europe. The Emiratis are now allowed to travel to these 34 countries for business or tourist purposes and stay there for up to 90 days in any 180-day period of one year. Since 9 other countries have lifted visa-requirements for Emirati nationals in the same year, in 2016 the UAE nationality's travel freedom improves significantly, going from 77 to 120 visa-free or visa-on-arrival destinations. As a direct consequence of these international developments, the UAE takes a jump forward from 36.3 percent in 2015 to 44.5 percent in QNI 2016 - an increase of 8.2 percent points. This increase corresponds to a significant improvement in ranking as well, bringing the Emirati nationality from the 62nd place in 2015 to the 49th place this year, overtaking Qatari nationality and ending up right below the nationality of Israel (48th).

The jump in the quality of the UAE nationality sends a very clear message: the possibility to travel in freedom matters greatly, both in qualitative and quantitative terms. As a result of diplomatic efforts and strengthened ties between the EU and the UAE, the latter has been able to grant its nationals extremely valuable assets. The Emirati nationality's improvement illustrates how international agreements can objectively entail concrete and measurable successes for millions of individuals.

\section{$5 \quad$ Conclusion}

The Quality of Nationality Index presents a reality that is often regrettable. It is far more comforting to assume that the quintessence of a nationality lies in patriotism and other subjective feelings of attachment towards one's state, effectively making any comparison between nationalities worthless or even impossible. Nevertheless, as the concepts of nationality and citizenship continue

Croatia to which not yet all Eu citizens currently have settlement access) plus Iceland, Norway, Switzerland, and 7 French overseas territories), leaving only settlement access to Georgia and Gibraltar. Normalized diversity of settlement freedom will decrease from 12.95 to 0.68 on a $0-15$ scale, and normalized weight of settlement freedom from 13.49 to 0.60 on a $0-15$ scale. The overall value of $U \mathrm{~K}$ nationality will consequently drop from 79.18 percent to 54.01 percent, or from 12th place to 34th place on the QNI General Ranking. This is under the presumption that $\mathrm{UK}$ nationals will keep visa-free travel access to all EU and EEA countries. 
to evolve, it is absolutely clear that mainstream thinking about nationality and citizenship has become obsolete. Nationalities are not equal, as least not under the assumption that the level of expected welfare, education, healthcare, life chances, and global travel and settlement opportunities matter.

Given that nationalities are quantitatively comparable in value, and moreover, that the citizenship rights attached to particular nationalities are in many cases not restricted to the territory of the conferring state, measuring the value of nationalities is key in order to make the huge divergences transparent. While some outcomes are perhaps predictable - for example the value of being an $\mathrm{EU}$ citizen and thus able to settle anywhere in the EU - the QNI is the first index that quantifies these predictions in hard numbers. It is by looking at the QNI that an EU citizen can actually see how much EU membership adds to the value of his or her passport. More broadly, the QNI allows both individuals and states the opportunity to reflect critically on the value of their nationalities. Some nationalities are far more valuable than others, and while this is not a pleasant message for everyone, the transparency that the QNI aims to provide is a necessary instrument in the acknowledgement of reality. 